\title{
Urgensi Calon Independen Dalam Pemilihan Kepala Daerah Langsung
}

\section{Elza Faiz}

\section{Abstrak}

If the Election Head of Region can be used as a momentum of fundamental change, thus the attendence of independent candidate is absolute and cannot be bargained. Practically and theorethically, independent candidate is significant.

\section{Pendahuluan}

Secara konstitutif, UUD 1945 sama sekali tidak mengatur secara ketat tentang syarat pencalonan dalam pilkada. Berbeda dengan kebjjakan mengenai pilpres yang mengharuskan pencalonan Presiden dan Wapres wajib melalui parpol atau gabungan parpol. Dengan demikian, dalam konteks pilkada konstitusi secara implisit memberikan perintah bahwa rakyat harus diberi space yang luas untuk berkontestasi, termasuk kehadiran calon independen atau calon yang tidak memiliki afiliasi dengan parpol.

Sayangnya, amanat implisit yang di wasiatkan konstitusi tersebut gagal disikapi secara tepat oleh pembuat undang-undang. Bukti empirisnya Undang-undang No 32 Tahun 2004 pasal 56 ayat (2) dan pasal 59 ayat (1) secara diskriminatif hanya mengakui parpol sebagai satu-satunya pintu pencalonan dalam pilkada. Ketentuan tersebut membuat peluang calon independen untuk tampil di pilkada menjadi tertutup.

Tulisan ini di konstruk untuk menyibak poin-poin penting tentang kehadiran calon independen dalam pilkada. Termasuk di dalamnya akan sedikit mengungkap tentang potret buram wajah parpol di Indonesia terkait dengan relevan tidaknya parpol sebagai satusatunya pintu pencalonan pilkada.

\section{Pentingnya Calon Independen Dalam Pilkada}

Ada beberapa argumentasi yang dapat di jadikan dasar untuk mengungkap pentingnya calon independen dalam pilkada, berikut penjelasannya:

\section{Mengamputasi Praktek Money Politics Dalam Pengajuan Kandidat}

Gagasan demokrasi langsung dalam memilih pemimpin politik dari perspektif antikorupsi sejatinya guna menghindari jual beli suara di parlemen, selain guna meningkatkan legitimasi dan akuntabilitas publik mereka. Sejak era reformasi hampir setiap pemilihan kepala daerah (Pilkada) di Tanah Air senantiasa diwarnai dengan politik uang di DPRD. 
Bentuk politik uang tergantung dengan sistem pemilu yang diterapkan. Ada empat moda korupsi pemilu yang beitemali dengan politik uang, yaitu beli suara (vote buying), beli kandidat (candidacy buying), manipulasi pendanaan kampanye dan manipulasi administrasi dan perolehan suara (administrative electoral comuption). ${ }^{1}$

Dalam konteks pilkada langsung, praktek beli suara hampir tidak efektif, karena skalanya yang amat luas, sehingga pembelian suara dalam jumlah besar tidak akan menjamin adanya loyalitas pemilih yang dibeli. Berbeda tentunya dengan politik uang di DPRD dengan jumlah pemilih yang kecil dan relatif homogen akan lebih aman, mudah, dan murah.

Namun, bebas dari satu mode korupsi tidak otomatis akan bebas pada mode korupsi yang lain. Dalam pilkada, dengan adanya kebijakan yang menggariskan bahwa satu-satunya pintu untuk pencalonan kepala daerah hanya melalui partai dan gabungan partai yang menguasai 15 persen dari jumlah kursi di DPRD atau 15 persen dari akumulasi suara pemilu legislatif, maka sangat dikhawatirkan akan terjadi korupsi pembelian kandidat (candidacy buying).

Modus operandinya bisa jadi parpol atau gabungan parpol yang memenuhi syarat akan mendekati calon yang berkantong tebal lalu menjual tiket kewenangannya pada sang calon, tentu saja disertai bandrol harga dan kontrak politik ekonomis tertentu. Atau seperti yang ditulis Teten ${ }^{2}$ bisa juga parpol menggelar semacam tender terbuka untuk mencari calon, dan sudah dapat dipastikan bahwa tender akan di menangkan oleh the highest bidder (penawar tertinggi).

Praktik semacam itu semakin dimungkinkan karena dua hal, pertama, tidak adanya ketentuan yang jelas dalam undangundang mengenai pelarangan politik uang dalam seleksi pencalonan kepala daerah. Kedua, di hadapkan pada persoalan parpol di indonesia yang belum bisa mandiri secara finansial dengan mengandalkan iuran dari anggotanya. Berbeda dengan parpol di luar negeri yang relatif sudah mapan dari iuran anggotanya. Kondisi tersebut membuat partaipartai di indonesia tergerak untuk mencari sumber pendanaan dari luar yang rawan terhadap terjadinya praktik korupsi. ${ }^{3}$

Dalam kenyataan di lapangan, kekhawatiran di atas menemui bentuk nyata, seperti yang suarakan oleh I Wayan Sudirta; salah satu anggota DPD RI bahwa ia mendengar calon yang mendaftar lewat partai sudah dimintai uang muka Rp 800 juta, kalau jadi kepala daerah ditambah Rp 1, 2 miliar. Salah satu sebabnya menurut I Wayan adalah karena kelemahan UU No. 32 tahun 2004 yang hanya mengakui parpol sebagai satu-satunya pemegang tiket di pilkada. Sehingga parpol dapat memeras calon kepala daerah agar bisa diloloskan dalam proses pencalonan. ${ }^{4}$

\section{Teten Masduki, "Pilkadal Rawan Politik Uang", Artikel di Harian Kompas, 11 Februari 2005. \\ ${ }^{2}$ bid}

${ }^{3}$ Pendapat Todung Mulya Lubis dalam Harian Kompas 26 Desember 2005 saat mengomentari hasil survey Gallup Intemational yang memberikan temuan mengejutkan bahwa parpol adalah institusi terkorup di Indonesia dengan indeks 4,2, disusul DPR (partemen) dengan indeks 4,0, kemudian Kepolisian dengan indeks 4,0 , dan bea cukai indeks 4,0. Data tersebut merupakan hasil survei terhadap 55.000 responden di 69 negara, termasuk indonesia. Skala survei ini adalah 1 hingga 5, di mana poin 1 berarti tidak ada korupsi dan 5 sangat banyak korupsi. Dengan angka melebihi empat tersebut, dapat dikatakan bahwa korupsi diparpol nyaris sempuma.

${ }^{4}$ Suara Pembaruan, 10 Desember 2004 
Dengan demikian, dari perspektif anti korupsi, konsepsi pilkada langsung masih belum tepat sasaran. Sebab di dalamnya masih ada rumusan yang memungkinkan terjadinya praktik candidacy buying. Untuk mengeliminasi praktik tersebut, selain harus ada ketentuan yang ketat mengenai pelarangan politik uang dalam proses pencalonan, juga harus ada kebijakan baru yang memungkinkan calon untuk dapat maju secara perorangan tanpa harus membeli tiket pada parpol, yaitu menyokong tampilnya calon independen.

\section{Membebaskan Kepala Daerah Terpilih dari Jerat Konsesi Parpol}

Salah satu kelebihan pemilihan langsung adalah kandidat terpilih tidak perlu terikat pada konsesi parpol atau faksi-faksi politik yang memilihnya. Ini diperlukan agar kandidat terpilih dapat berdiri di atas setiap kepentingan dan mampu menjembatani berbagai kepentingan tersebut. Dalam konteks pilpres misalnya, Apabila Presiden terpilih tidak dapat mengatasi kepentingan-kepentingan parpol, maka kabinet yang dibentuk cenderung merupakan kabinet koalisi parpol dan bukan kabinet kerja. Padahal pada masa krisis ekonomi seperti sekarang ini, yang kita perlukan adalah kabinet kerja. ${ }^{5}$ Sementara pada konteks pilkada, apabila kepala daerah terpilih tidak mampu keluar dari bayang-bayang konsesi politik parpol, maka sulit baginya untuk bekerja secara otonom. Hal ini kemudian akan berpengaruh terhadap netralitas kebijakan yang akan digulirkannya.

Sarat otonomi kekuasaan eksekutif tersebut bila dikaitkan dengan kebutuhan sistem pemerintahan presidensial juga relevan, karena akan menciptakan cheks and balances antara eksekutif dan parlemen. Sebab memang dalam sistem presidensiil, kekuasaan antara eksekutif dan parlemen berada dalam posisi seimbang/sejajar.

Namun, sesungguhnya untuk mewujudkan kemandirian eksekutif dan bebas dari konsesi parpol, sebenarnya tidak cukup hanya dengan pemilihan langsung, tetapi lebih dari itu proses kontestasi kandidat dari awal juga harus di-drive agar kandidat tidak harus memakai parpol sebagai kendaraan politiknya. Sebab walaupun dipilih secara langsung, tetapi proses pencalonan masih wajib dan mutlak melalui parpol, maka sang calon tetap akan merasa berhutang politik terhadap parpol sebagai kendaraan yang mengusungnya.

Contoh paling mutakhir adalah Presiden Susilo Bambang Yudhoyono yang memenangkan kontestasi pilpres langsung kemarin. Ketika ia dipilih langsung oleh rakyat, mestinya ia percaya diri dan tidak perlu mendasarkan kabinetnya dengan memasang banyak kaki partai didalamnya. Sebab yang berjasa menaikkan dirinya menjadi Presiden adalah suara rakyat, bukan suara partai. Hal itu juga sejalan dengan bangunan sistem pemerintahan presidensil yang dicirikan dengan kuatnya legitimasi dan wewenang Presiden untuk merancang komposisi pemerintahan. ${ }^{6}$ Tetapi

\footnotetext{
${ }^{5}$ Smita Notosusanto, Usulan Pemilihan Presiden Langsung", www.cetro.orid , 20 Agustus 2001, Pukul 21.33WIB.

${ }^{6}$ Presiden memiliki wewenang penuhuntuk menentukan komposisi kabinetkarena dalam system Presidensil, posisi Presiden adalah eksekutif tunggal yang bertanggung jawab langsung kepada para pemilih/rakyat, bukan kepada majelis. LihatArendj Lipjhart, Sistem Pemerintahan Parlementer dan Presidensial. (Jakarta: PT Raja Grafindo Persada, 1995), hlm.43-50.
} 
SBY tidak mampu menempatkan diri pada posisi itu karena dia berangkat dengan kendaraan gabungan partai, sehingga ia tidak mampu melepaskan dirinya dari berondongan tuntutan kekuasaan pragmatis partai yang mengusungnya. ${ }^{7}$ Fenomena ini sekaligus menunjukkan sebuah bentuk paradoks demokrasi di Indonesia.

Dalam pilkada juga berpotensi demikian, dengan adanya ketentuan dalam UU No 32 Tahun 2004 pasal 56 ayat (2) dan pasal 59 ayat (1) bahwa satu-satunya pintu pencalonan adalah parpol atau gabungan parpol yang menguasai 15 persen dari jumlah kursi di DPRD atau 15 persen dari akumulasi suara pemilu legislatif. Maka mustahil sistem ini akan membebaskan kepala daerah terpilih untuk dapat berdiri otonom. Apalagi dengan threshold 15 persen maka akan semakin banyak parpol yang di butuhkan sebagai kendaraan politiknya. Konsekuensinya akan memposisikan kepala daerah seperti di kerubung atau dikeroyok oleh kepentingan banyak parpol yang mengusungnya atas nama balas jasa.

Berangkat dari analisis itu, maka dapat dipastikan bahwa kehadiran calon independen menjadi kontekstual dan relevan untuk menciptakan kemandirian eksekutif (baik Presiden maupun Kepala Daerah) agar dapat berdiri di atas setiap kepentingan. Sekaligus untuk mengeliminasi paradoks demokrasi di Indonesia yang makin mewujud.

\section{Sebagai Substitusi Kekecewaan Rakyat Terhadap Calon Pilihan Parpol}

Reformasi yang menyeruak di penghujung Mei 1998 dan ditandai dengan tumbangnya Soeharto dari kursi kekuasaan, awalnya disambut rakyat dengan suka cita dan gegap gempita. Rakyat menganggap bahwa inilah momentum untuk keluar dari beban krisis yang tak henti-henti menderanya. Mereka pun menggantungkan ekspektasi bahwa pemerintah pasca Soeharto akan mampu memberikan insentif dalam mewujudkan impiannya tersebut. Salah satu bentuk ekspektasinya ditunjukkan dengan ledakan partisipasinya dalam pemilu 1999 yang mencapai 90 persen angka partisipasi. ${ }^{8}$ Bahkan Arief Budiman, yang dikenal sebagai pencetus golput dalam pemilu 1971 , ternyata pada pemilu 1999 dilaporkan menggunakan hak pilihnya karena dia memiliki harapan akan terjadi perubahan mendasar. ${ }^{9}$

Namun, harapan akan terjadinya perubahan mendasar pasca pemilu 1999 tak kunjung tejjadi, alih-alih memperjuangkan kepentingan rakyat, wakil-wakil rakyat yang notabenenya berasal dari parpol justru asyik dengan kepentingannya sendiri. sementara kemiskinan, ketidakadilan, kenaikan harga, konflik horizontal, ketidak-

'Tentu saja analisa ini terlepas darigaya kepemimpinan politik SBY. Gaya kepemimpinan yang akomodatif terhadap setiap faksi politik atas dalih stabilitas pemerintahan. bukan didasarkan atas kesamaan visi dan misi untuk kebutuhan pemerintahannya.

${ }^{8}$ Data angka partisipasi pemilih dikutip dari lgn Ismanto (dkk), Pemilihan Presiden Secara Langsung 2004, Dokumntasi, Analisis dan Kritik, (Jakarta: Kerjasama Kementrian Riset dan Teknologi dan Departemen Politik dan Perubahan Sosial CSIS, 2004), hlm 123

${ }^{9}$ LihatArif Budiman, "Bila Megawati Jadi Presiden, Mengerikan", dalam Dari Bilik Suara Ke Masa Depan Indonesia, Potret Konfik politik Paca Pemilu Dan Nasib Reformasi. (Jakarta: PT Raja Grafindo Persada, 1999), him. 190 
amanan dan rasa takut ancaman kejahatan, dan lain-lain yang dialami rakyat tak pernah dihiraukannya. ${ }^{10}$

Faktor tersebut memberikan kekecewaan dan rasa muak tersendiri bagi rakyat terhadap elit-elit parpol. Akibatnya, pada pemilu 2004 sebagai pemilu kedua pasca reformasi, ledakan partisipasi tidak terulang lagi. Yang terjadi justru menurunnya angka partisipasi mereka yang hanya mencapai 84 persen. Penurunan angka partisipasi tersebut kemudian terus meluas dalam Pilpres putaran pertama dengan angka 78 persen partisipasi pemilih dan menurun lagi dalam pilpres putaran kedua yang hanya menyentuh angka 75 persen. ${ }^{11}$

Tidak berhenti sampai di pilpres, angka penurunan partisipasi pemilih terus merangsek sampai ke pilkada. Buktinya dalam pilkada kabupaten/kota ditemukan fakta politik bahwa jumlah 'golput' lebih besar prosentasenya dibandingkan dengan prosentase perolehan suara pasangan pemenangnya. Di sejumlah daerah, pemilih yang tidak menggunakan hak pilihnya alias golput mencapai angka 30 persen.
Bahkan Di daerah lain ada yang mendekati 50 persen. Misalnya, di Surabaya, golput mencapai 48,32 persen atau 934.794 pemilih. Jumlah ini hampir dua kali lipat pemilih Pasangan Bambang $\mathrm{DH}$ - Arief Affandi, pemenang pemilihan dengan 492.999 pemilih. ${ }^{12}$

Fenomena menurunnya angka partisipasi tersebut semakin menasbihkan bahwa kekecewaan rakyat terhadap elit parpol semakin memuncak. Bahkan kalau tidak di antisipasi akan sampai pada titik ekstrim. Konsekuensinya pemilu/pilkada akan kehilangan legitimasinya sebagai pentas demokrasi, karena tidak disertai partisipasi mayoritas rakyat. Kondisi ini selanjutnya akan mengantarkan satu ancaman baru dalam demokrasi di Indonesia, yaitu meminjam istilah Olle Tornquist muncuinya hantu 'demokrasi kaum penjahat'.'

Karena itu, untuk menjawab persoalan di atas, maka kemunculan calon independen bisa menjadi alternatif solusi. Kehadirannya dalam konteks ini dapat diposisikan sebagai substitusi kekecewaan rakyat terhadap ketidak becusan calon-calon yang di usung oleh parpol.

${ }^{10}$ Lili Romli, "Potret Buram Partai Politik Di Indonesia", dalam Menggugat Partai Politik. Jakarta: Laboratorium IImu Politik Fisipol UI, 2003), hlm.142

"Election Guide - IFES website, www ifes.org/eguide/tumout2004.htm. Menununnya partisipasi rakyat juga dapat diukur dari merosotnya perolehan suara partai-partai besar reformasi, seperti PDIP, PKB dan PAN. Terutama PDIP, sebagai partainya Presiden menurun suaranya dari 33,7 persen di pemilu 1999 menjadi hanya 18,5 persen di pemilu 20004. Sementara PKB turun dari 12,6 persen menjadi 10,6 persen, dan PAN dari.7,1 persen menjadi 6,4 persen. untuk data ini lihat Castle, Lance, Pemilu 2004 dalam Konteks Komparatif Dan Historis. (Yogyakarta: Pustaka Pelajar, 2004), hlm. 44.

12 Tim Akbar Tandjung Institute; Ibrahim Ambong, M.Alfan Alfian, M.Agustin Prasetya, Puji Wahono, dan A.Doli Kumia dalam "Evaluasidan Peran Partai Politik", AT Institute Online, 03 Februari 2006. Pukul 20.21 WIB

13 'Demokrasi kaum penjahat' menunjuk pada satu kondisi dimana demokrasi hanya berjalan secara formal tetapi tidak di sertai oleh partisipasi rakyat yang sungguh-sungguh dalam pemilu dan dalam pembentukan kebijakan pemerintah. Hasil yang lebih terlihat karenanya adalah munculnya 'demokrasi kaum penjahat' dimana aktor-aktor yang bermain hanya mementingkan kepentingannya sendiri tanpa berkorelasi dengan kepentingan rakyat yang mesti diwakilinya. Lihat R. William Liddle (peng), dalam Juan J. Linz, Menjauhi Demokrasi Kaum Penjahat, Belajar dari Kekeliruan Negara-Negara Lain. (Bandung: Mizan, 2001), hlm. 17 
Substitusi ini sekaligus akan berkontribusi terhadap perfuasan hak-hak konstitusional rakyat dalam panggung elektoral, baik dalam konteks right to vote maupun right to be candidate. ${ }^{14}$

Tidak hanya itu, adanya substitusi tersebut juga sejalan dengan praktik berdemokrasi. rakyat indonesia yang tercermin dalam praktik pemilihan kepala desa, dimana dalam setiap pemilihan kepala desa apabila calon/ kandidatnya tunggal, maka disediakan "kotak kosong" sebagai lawan. "kotak kosong" tersebut merupakan simbol oposisi gaya desa. Bahkan dalam beberapa kasus menunjukkan bahwa masyarakat desa lebih memilih "kotak kosong". Bayangkan kalau kreasi genius gaya desa ini dibawa ke tingkat yang lebih tinggi seperti pemilu legislatif, pilpres maupun pilkada, maka dalam situasi seperti sekarang, bisa jadi yang menang atau yang menjadi. anggota DPR, Presiden, Gubernur, Bupati/ walikota adalah "sang kotak kosong". ${ }^{15}$ Dalam konteks kekinian, "kotak kosong" tersebut dapat di tafsirkan sebagai kandidat independen.

Dengan demikian, adanya substitusi tersebut, bisa jadi akan menggerakakan rakyat untuk berpartisipasi dan berkontestasi, sebab hak-hak konstitusional dan tradisi berdemokrasi mereka kini telah diakomodir. Pilkadapun akan menemukan kembali "wajah" demokratisnya.

\section{Sebagai Rival Strategis yang Akan Menyehatkan Parpol}

Pemilihan Presiden, Pemilihan Dewan Perwakilan Daerah (DPD) dan Pilkada langsung yang telah digelar dapat menjadi referensi dan bukti empiris untuk menunjukkan bahwa parpol ternyata tidak mampu menjadi magnet dalam menarik dukungan pemilih bagi kandidat-kandidat yang tampil dalam pentas pemilihan.

Dalam pilpres misalnya, sejak putaran pertama Susilo Bambang Yudhoyono mengungguli lawan-lawannya dengan selisih cukup besar, padahal ia hanya didukung oleh sejumlah partai kecil. Pada putaran pertama ia hanya didukung oleh Partai Demokrat, Partai Bulan Bintang, dan Partai Keadilan dan Persatuan Indonesia. Total perolehan suaranya kurang lebih hanya sekitar 10 persen. Jumlah ini jauh dibawah perolehan suara SBY, yakni 36 persen. la mengalahkan Megawati yang berkekuatan PDI Perjuangan (setidaknya 18 persen), dan Wiranto yang berkekuatan Partai Golkar dan PKB (setidaknya 32 persen). Di putaran kedua ia mengalahkan Megawati dengan perolehan suara 61 persen, padahal total pemilih partai yang resmi mendukung Megawati (PDIP, Partai Golkar, PPP, PDS, PDU, dan sejumlah partai kecil lainnya) diatas 50 persen. ${ }^{16}$

${ }^{14}$ Dalam konteks right to vote misalnya, adanya subtitusi tadi akan membuat rakyat/pemilih lebih memiliki banyak pilihan dan tidak lagi di "sandera" untuk memilih calon yang di plot oleh parpol. Sementara dalam konteks right to be candidate, rakyat akan dapat berkontestasi langsung secara perorangan tanpa harus "berselingkuh" dengan parpol, sebab belum tentu rakyat/calon memiliki ideologi/keyakinan politik yang sama dengan semua parpol didaerahnya

${ }^{15}$ Lihat dalam Rufinus Lahur," Keterbukaan Politik, Kepemimpinan, dan Ketidak Pastian" dalam Bantarto Bandoro dkk (Penyunting), Refleksi Setengah Abad Kemerdekaan Indonesia, (Jakarta: CSIS, 1995), hlm 108.

${ }^{16}$ Untuk data lengkap tentang perolehan suara di pilpres serta analisa kekalahan dan kemenangan pasangan calon, lihat Ign Ismanto. Op.cit. hlm,71-84 
Dalam Pemilu untuk DPD juga demikian, kalau memperhatikan latar belakang anggota DPD terpilih sekarang, hanya 6 orang dari 128 anggota DPD (sekitar 5 persen) yang berlatar belakang kental partai politik. Selebihnya adalah tokoh-tokoh yang relatif tidak mempunyai latar belakang aktif dipartai politik. Mereka pengusaha, professional, intelektual, birokrat, atau tokoh Ormas. ${ }^{17}$

Sementara dalam pilkada yang telah dilangsungkan selama bulan juni 2005 juga menyodorkan fakta paradoksal bahwa tidak ada korelasi kuat antara dukungan rakyat pada partai dalam pemilu legislatif dan dalam pilkada. Partai-partai yang menang dalam pemilu legislatif banyak mengalami kekalahan telak dalam pilkada. Sedangkan partai kecil atau gabungan partai guram justru muncul dengan kemenangan meyakinkan. Persis seperti yang terjadi dalam pilpres.

Di Semarang misalnya, pasangan Sukawi Sutarip dan Mahfudz Ali yang unggul mutlak dengan perolehan suara di atas 73 persen, bukan dicalonkan oleh PDI Perjuangan atau Partai Golkar yang dalam Pemilu Legislatif 2004 menduduki peringkat teratas. Sebaliknya, pasangan calon yang diusung PDI Pejuangan justru jeblok dan menduduki unutan paling bawah. Demikian juga yang dicalonkan Partai Golkar, hanya mencapai peringkat ketiga dengan selisih perolehan suara yang sangat tajam. Hal serupa juga terjadi di beberapa daerah lain. ${ }^{18}$
Demikian juga dengan Pilkada di Banyuwangi, pasangan Ratna Ayu Lestari dan Yusuf Noris yang notabenenya hanya didukung oleh 18 partai kecil (non parlemen), mengalahkan empat kandidat lain yang didukung partai besar seperti pasangan Akhmad Wahyudi HM Eko Sukartono yang dicalonkan PKB, pasangan Masduki Suut - Syafii yang di sokong oleh koalisi PPP dan Partai Demokrat, pasangan Susanto Suwandi - Abdul Kadir dari partai Golkar, dan pasangan Ali Sahroni-Yusuf Widjiatmoko yang di dukung PDIP. 19 $^{9}$

Kalaupun pada beberapa daerah yang dimenangkan oleh pasangan calon yang didukung parpol besar, dimungkinkan kemenangan itu bukan disebabkan karena bergeraknya mesin partai sebagai vote getter, tetapi lebih disebabkan oleh faktor popularitas sang calon, selain itu juga disebabkan faktor bahwa calon yang bersangkutan adalah calon incumbent (pejabat terdahulu). Berdasar catatan litbang Media Indonesia ${ }^{20}$ misalnya, dari 106 daerah (khususnya kabupaten/kota) yang pilkada-nya dilkuti oleh calon incumbent, yang kalah hanya 30 daerah. ${ }^{21}$

Kenyataan di atas menunjukkan bahwa parpol dalam pemilhan langsung adalah tidak penting. Karena ia terbukti tidak mampu menjadi mesin politik yang strategis dan menentukan. Dalam pemilihan langsung, menurut Lance Castles, ${ }^{2}$ rakyat akan lebih berfokus pada sosok sang calon dan relatif lepas dari keterikatan

${ }^{17}$ Saiful Mujani, “Pilkada, Kekuatan Partai dan Signifikasi Calon”, Media Indonesia Online, 09 Desember 2005.Pukul 12.24. WIB

${ }^{18}$ Suara Merdeka Online,29 Juni 2005, Pukul 17.10. WIB

19 Jawa Pos, 12 Agustus 2005

${ }^{20}$ Dikutip dari Tim Akbar Tandjung Institute. loc.cit.

${ }^{21}$ Terakhir calon incumbent mencatat kemenangan lagi dalam Pilkada Kabupaten Tuban yang sempat menimbulkan kerusuhan.

${ }^{2}$ Lance Castles. op.cit., hlm. 44. 
organisasional seperti parpol.

Fakta tersebut juga menasbihkan bahwa masyarakat pemilih di Indonesia semakin otonom. Mereka bukan lagi objek pasif yang mudah didikte dan dijajah pilihan politiknya oleh keputusan partai yang acapkali sentralistik, pragmatis dan mengabaikan aspirasi konstituennya. Sebaliknya, masyarakatjustru lebih berperan sebagai subjek rasional yang secara sadar mampu menentukan sendiri calon pemimpinnya.

Karena itu, ketika partai-partai telah gagal sebagai kendaraan kemenangan calon. maka patut dipikirkan untuk mengamandemen undang-undang sehingga bisa membuka jalan bagi calon independen. Dengan demikian parpol akan memiliki rival/ kekuatan penyeimbang yang akan membuatnya belajar dan berbenah, dan pada akhimya akan menyehatkannya.

\section{Menghambat Laju Kelompok Oligarki Kapitalis Lama Di Indonesia}

Tumbuhnya kekuatan kapitalis domestik di Indonesia pada penghujung dekade 80-an hanya dapat dijelaskan dengan menghubungkannya pada peran negara yang sangat dominan dan sentralistik. Tidak saja dengan monopoli langsung atas akses sumber daya ekonomi tetapi juga posisinya yang sangat menentukan dalam pengaturan dan pengalokasiannya. Namun demikian, adalah keliru untuk membayangkan bahwa sistem pengaturan dan pengalokasian akses sumber daya ekonomi itu dilakukan melalui cara cara fair sebagaimana yang terjadi didalam sistem ekonomi kapitalis liberal melainkan melalui jaringan patronase yang berpusat pada Soeharto. Jaringan patronase ini sendiri melibatkan para anggota keluarga Soeharto, klik politik petinggi Negara, dan segelintir kapitalis Tionghoa. ${ }^{23}$

Sistem kapitalisme negara sendiri awalnya dibangun dengan mendominasi minyak, pertambangan dan sektor-sektor sumberdaya alam, infrastruktur, perbankan, dan perdagangan. Kapitalisme negara kemudian mencapai puncak selama tahun-tahun boom minyak 1978-1982, ${ }^{24}$ dimana koper-koper negara padat dengan petrodolar. ${ }^{25}$ Akan tetapi dalam perkembangannya, sistem kapitalisme negara terpecah juga oleh krisis anjloknya harga minyak pada tahun 1981-1982 dan sekali

${ }^{23}$ Paragraf 1-5 dalam pembahasan inj semuanya disarikan padahasil kajian Verdi $R$ Hadiz disertai tambahan referensi untuk keterangan. Lihat Verdi R Hadiz, Dinamika Kekuasaan Ekonomi Politik Indonesia Pasca Soeharto, (Jakarta: LP3ES. 2005), hIm. 105-167.

${ }^{24}$ boom minyak terdiri dari dua fase. Antara 1973 dan 1974 , harga minyak internasional naik dari sekitar US $\$ 3$ perbarel menjadi lebih dari US $\$ 40$ per barel. Sebagai akibatnya, ekspor minyak dan gas Indonesia melonjak dari US $\$ 1,6$ juta atau 50,1 persen total ekspor tahun 1973 , menjadi US $\$ 18,4$ juta atau 82,6 persen total ekspor tahun 1982. bersamaan dengan itu pula, pendapatan pemerintah dari ekspor pajak minyak dan gas meningkat dari RP 392 Miliar atau 39,5 persen total pemasukan tahun 1973 , menjadi Rp 8,6 Trilyun, atau lebih dari 70 persen total pemasukan pemerintah tahun 1981-82. Lihat, Republik Indonesia, "Nota Keuangan dan Rancangan Anggaran Pendapatan dan Belanja Negara Tahun Anggaran 1994/1995".

${ }^{25}$ Setelah mendapat rezeki nomplok dari minyak tersebut, Soeharto membentuk "Tim Sepuluh" dibawah kekuasaan Sekretariat Negara (berkait langsung diatasnya adalah Golkar) yang diberi kuasa untukmenguasai semua proyek diatas 500 juta, serta menguasai pengambil alihan tanah untuk proyek-proyek baru dan memberi 
lagi pada tahun 1986. Krisis anjloknya harga minyak secara dramatis tersebut menggeser pilihan-pilihan bagi para pemain utama. Hal ini menjadi lampu kuning bagi muculnya kebutuhan untuk memobilisasi sumbersumber dana investasi baru dari sektor swasta dengan membangun industri-industri ekspor dan membangun basis-basis pemasukan baru. bahkan dalam perkembangan selanjutnya krisis ini juga mengakibatkan lembaga donor internasional melakukan desakan kepada pemerintah untuk menjalankan paket deregulasi ekonomi.

Namun, deregulasi yang awalnya dimaksudkan untuk memupus praktik-praktik monopoli negara atas berbagai sumber daya ekonomi dalam rangka menumbuhkan sebuah perekonomian yang lebih berorientasi kepada pasar liberal gagal diwujudkan. Hal ini tidak lain karena para penikmat deregulasi adalah kaum oligarki. ${ }^{26}$ Bukannya meliberalkan pasar, yang terjadi justru melicinkan jalan bagi pemindahan monopoli negara atas akses sumberdaya ke tangan para oligarki. Pada titik inilah 'penjarahan sistematis' yang dilakukan kelompok oligarki atas berbagai akses sumberdaya produktif yang sebelumnya berada dibawah kendali negara dimulai.

Lebih dari sekedar menguasai akses ke berbagai sumberdaya ekonomi, kaum oligarki (dalam bahasa Vedi R Hadiz, kelompok ini disebut sebagai predator) juga berupaya melakukan penguasaan terhadap lembagalembaga politik sebagai instrumen untuk menjamin langgengnya dominasi mereka. Karena itu, sejak dekade 1980-an, Golkar yang sebelumnya partainya negara segera beralih sebagai kendaraan politik kaum oligarki. Mengingat bahwa partai ini kerapkali memenangkan pemilu, maka tidaklah mengherankan kalau kaum oligarki ini juga memperoleh posisi diparlemen. Kondisi inilah yang terus bertahan selama sekitar satu dekade hingga akhirnya mengantarkan Indonesia terhempas badai krisis finansial ditahun 1997 dan menyapu struktur bangunan ekonomi politik orde baru ditahun 1998 yang ditandai dengan terjungkalnya salah seorang diktator paling kuat didunia- Soeharto- dari kursi kekuasaannya.

Bersamaan dengan itulah, sejumlah analis baik dalam maupun luar negeri mulai melontarkan gagasan teori bahwa perjalanan Indonesia pasca soeharto pasca 1998 akan menempuh trayek mulus untuk mencapai format politik demokratis dan ekonomi liberal. Namun kenyataannya, meskipun struktur ekonomi-politik orde baru runtuh berkepingkeping, perubahan-perubahan yang terjadi hanyalah pada konteks, dan oleh karena itu, ia tidak mengubah basis material yang

izin bagi proyek sekaligus mengontrol proyek. Pada bulan Juli 1980 Presiden mengeluarkan keputusan memperluas kekuasaan "Tim Sepuluh" untuk menguasai semua perusahaan negara, dengan Pertamina sebagai hadiah terbesar". Sementara untuk strategi politik rezim, kelebihan dana dari minyak, digunakan oleh Orde Baru untuk membiayai kekerasan disegala bidang: (khusus untuk keterangan ini, lihat Daniel Dhakidae, Cendekiawan dan Kekuasaan dalam Negara Orde Baru, (Jakarta: Gramedia Pustaka, 2003), hlm. 282-284

${ }^{2} \mathrm{~K}$ Keluarga Soeharto misalnya, mematrikan posisinya sebagai perusahaan pemain utama ketika ia memenangkan kontrak-kontrak kunci dan lisensi-lisensi dibidang industri pembangkitl listrik, pembangunan jalan dan pelabuhan, serta konstruksi penyulingan dan industri petrokimia. Keterangan ini dikutip Verdi dari Robison 1997,"Politics and Market In Indonesia; Post-Oil Era “ dalam G.Rodan. K. Hewison dan R.Robinson, (eds), The Political Economy of Southeast Asia:An Introduction, (Melboume: Oxford University Pers), hlm.54. 
sesungguhnya. Sebab proses dominasi elit orde baru beserta kalangan oligarki tidak saja terhadap politik dan ekonomi, tetapi juga terhadap civil society pada dasarnya tetap berlangsung. ${ }^{27}$ Perbedaannya dengan masa lalu terletak pada cara melanggengkan dominasinya. Jika pada masar lalu dominasi dilakukan dengan menggunakan instrumen otoritas sentral negara, maka pada era pasca Soeharto dominasi dilakukan melalui berbagai partai politik, pemilu, parlemen, dan desentralisasi.

Bersandar dari kajian Verdi di atas, maka pilkada akan menjadi salah satu sasaran strategis bagi kaum oligarki kapitalis lama yang dibesarkan Orde Baru untuk mengkonsolidasikan kekuatan politik dan monopoli ekonominya dengan cara merebut kursi kepala daerah. Apalagi dengan kebijakan yang hanya mengakui parpol sebagai satu-satunya pemegang kunci pencalonan, maka dengan kekuatan finansial yang ia punya akan memudahkan kaum oligarki ini untuk memonopoli kontestasi pencalonan dengan membeli tiket pada parpol dan pada akhirnya mereka jugalah yang akan tampil sebagai penguasa-penguasa terdepan di negeri ini. ${ }^{28}$

Karena itu, untuk menghambat laju mereka dalam membangun kerajaan predatornya, maka pilkada harus membuka pintu seluas-luasnya untuk kontestasi calon, termasuk pintu bagi calon independen, agar rakyat dari berbagai latar belakang dapat berkontestasi secara fair, adil dan demokratis. Dengan demikian, terbuka peluang lahirnya kepala daerah yang benar-benar pro rakyat.

\section{Menggugat Monopoli Pencalonan Pilkada Oleh Parpol}

Keberadaan partai politik adalah syarat bagi negara yang menggunakan sistem demokrasi. Menurut Harun Alrasid misalnya (dengan mengutip Gustav Radbruch) berpendapat bahwa "kekuasaan rakyat berarti kekuasaan partai politik. Menentang eksistensi partai berarti menentang demokrasi". ${ }^{29}$ Senada dengan Alrasid, Ichlasul Amal dengan tegas mengatakan, "partai politik merupakan

\footnotetext{
${ }^{27}$ Amin Rais pemah mengatakan" Saya percaya bahwa proses reformasi total akan lebih mudah setelah soeharto turun dari kekuasaan. Saya mengasumsikan bahwa dia adalah hambatan terbesar reformasi dan, sefelah dia disingkirkan, saya percaya kami akan bisa mendesak dilakukannya reformasi dengan lebih mudah. Saya salah.....Sekarang saya sadar, piramida yang ditinggalkan Soeharto masih berdir" dikutip Verdi dariP Hartcer, 'The Father of Reform', The Australian Financial Review, (Mei 1999), hlm.56

${ }^{28}$ Sekedar catatan, menurut catatan litbang kompas, selama Juni 2005 , dari 125 kabupaten/kota yang melaksanakan hajatan politik lokal ini, setidaknya terdapat 80 daerah yang calonnya dari kalangan pengusaha (tidak menutup kemungkinan, beberapa pengusaha yang tampil dipilkada ini adalah kelompok oligarki lama. red). Jumlah ini merupakan peningkatan besar bila dibandingkan dengan periode sebelumnya yang hanya lima persen dari 415 kabupaten/kota di indonesia. Dari beberapa parpol yang berlaga, PDIP merupakan partai yang banyak menggaet calon dari kalangan pemilik modal ini. PDIP mengajukan 35 pengusaha sebagai calon kepala daerah dan calon wakil kepala daerah. walaupun hanya delapan daerah yang dimenagkan. Sementara golkar mencalonkan 25 calon dari kalangan yang sama (pengusaha) dan memenangkan sembilan daerah. (Selengkapnya Lihat Catatan Litbang Kompas, dalam Kompas 6 September 2005)

${ }^{29}$ Harun Alrasid, “Jabatan Presiden Republik Indonesia”, Dies rede pada Sidang Senat Terbuka Dies Natalis ke 56 Universitas Islam Indonesia, 8 November 1999, hlm.5
} 
keharusan dalam kehidupan politik yang modem dan demokratis". ${ }^{30}$

Namun pendapat yang menguntungkan posisi parpol tersebut harus diterapkan secara selektif dengan mengkontekstualisasikan pada kondiși obyektif parpol dimasing-masing negara. Sebab terdapat kecenderungan bahwa parpol dinegara-negara yang masih terbelakang bahkan tidak sedikit dinegara yang sudah demokratis cenderung memiliki dua wajah yang bertolak belakang. Satu sisi keberadaan parpol menjadi syarat bagi negara demokratis, tetapi di sisi lain tingkah polah parpol justru dapat berbahaya bagi tujuan demokratisasi itu sendiri. Dalam bahasa Duverger," Democracy is not threatened by the party regime but by present day trends in party international organization: the danger does not lie in the existence of parties but in the military, religious, and the totalitarian form from they sometime assume $^{\text {n31 }}$ Di indonesia, dengan kondisi dan tingkah polah parpol seperti yang sedikit banyak disinggung pada bab sebelumnya, tidaklah berlebihan kalau dikotakkan pada kecenderungan kedua. Yaitu berbahaya bagi tujuan demokrasi.

Dalam potret umum parpol seperti itu, maka kebijakan yang memberikan otoritas tunggal pada parpol dalam kontestasi kandidat disetiap pentas elektoral termasuk pilkada juga harus mendapat pengkritisan sekaligus gugatan. Dalam konteks ini pula penulis tergerak untuk mengajukan dua gugatan, pertama, parpol tidak memiliki kontribusi dalam setiap sejarah perubahan besar di Indonesia. Kedua, parpol tidak serius menggarap kaderisasi. Karena itu, kebijakan yang memberikan oforitas tunggal pada parpol dalam pencalonan pilkada menjadi tidak relevan. Berikut penjelasannya;

\section{a. Parpol tidak memiliki kontribusi dalam setiap sejarah perubahan besar di indonesia}

Sejarah revolusi dan perubahan besar dalam republik ini sesungguhnya lahir tanpa kontribusi parpol didalamnya. Dimulai dari Sumpah pemuda 28 oktober 1928 yang merupakan tonggak kedua pendirian NKRI tidak ditemukan peran parpol. Sumpah pemuda lahir setelah diawali inisiatif beberapa pemuda revolusioner seperti Moh. Yamin, Suyoto Hadinoto, J.Leimina, Rohyani, W.R. Soepratman, Adnan K.Gani dan lainnya untuk mengadakan Kongres yang bertujuan untuk mempersatukan pemuda. Meskipun Belanda semula ingin mensabot kongres tersebut, namun cita-cita nasionalisme-lah yang menang. Maka pada tanggal. 28 Oktober 1928 pukul 23.00 diwisma Indonesia, jalan Kramat 106, Jakarta dikumandangkan sumpah pemuda yakni; Satu Nusa, Satu Bangsa, Satu Bahasa: Indonesia. ${ }^{32}$ Ben Anderson menyebutkan, Sumpah pemuda itu sebagai revolusi pemuda tanpa parpol. ${ }^{33}$

${ }^{30}$ Ichlasul Amal (ed), Teori-Teori Mutakhir Partai Politik, (Yogyakarta: PT Tiara Wacana, 1996,) hlm. XV

${ }^{31}$ Maurice Duverger, 1959, Political Parties, hlm 425, dalam Denni Indrayana, "Pilkada: Demokratis atau Anarkis", makalah Diskusi Publik Bertema Implikasi Politik Dan Hukum Pencalonan Pilkada Tanpa Mekanisme Konvensi yang diselenggarakan oleh Impress bekerjasama dengan SKH kedaulatan Rakyat, tanggal 1 April 2005 di Yogyakarta.

${ }^{32}$ C.S.T. Kansil Dan Julianto, Sejarah Perjuangan Pergerakan Kebangsanaan Indonesia,(Jakarta: Erlangga, 1987), him. 39.

${ }^{33}$ Kompas, 5 Agustus 2002. 
Parpol juga tidak menunjukkan keterlibatannya dalam proses menuju Indonesia merdeka. Proklamasi 17 Agustus 1945 lahir atas desakan para pemuda yang terus memaksa Soekarno dan Hatta untuk segera memproklamirkàn kemerdekaan setelah jepang luluh lantak atas serangan bom atom pasukan sekutu yang akhirnya membuat jepang menyerah..$^{34}$

Begitu juga saat tumbangnya Orde Lama ditahun 1966 yang didahului beberapa peristiwa, seperti pembunuhan tujuh Jenderal AD pada 30 september $1965,{ }^{35}$ hiper inflasi yang mencapai 650 persen di tahun $1966 .^{36}$ membuat mahasiswa yang didukung militer berdemonstrasi besar-besaran, sampai berujung pada tumbangnya orde lama sekaligus menjadi awal kelahiran Orde 'Baru. Di sini juga tidak terlalu terlihat peran parpol. ${ }^{37}$

Sampai pada reformasi 1998 juga lahir tanpa kontribusi parpol, reformasi lahir dari massifnya gerakan mahasiswa, kekuatan pro demokrasi dan dari banyak tokoh-tokoh non parpol. Alih-alih memberikan kontribusi dalam sejarah reformasi, yang terjadi justru parpol dalam sejarah otoritarianisme Orde Baru melalui wakil-wakilnya di parlemen malah ikut menjadi rubber stamp dalam menunjang kekuasaan rezim predator tersebut.

Ironisnya sesudah Orde Baru tumbang, parpol mengambil keuntungan dengan mengambil alih kendali kekuasaan lewat tangantangannya di parlemen dengan meninggalkan mahasiswa, kekuatan prodemokrasi, bahkan juga meninggalkan rakyat. Parpol kemudian memproduk undang-undang yang dibuatnya sebagai instrumen pembenar kekuasaannya. Salah satu buktinya adalah dengan UndangUndang monopolinya untuk pengajuan calon dalam Pilpres dan pilkada. Sehingga parpol dengan demikian telah menguasai sistem pemilihan penguasa dari hulu hingga ke hilir; mulai dari pemilihan presiden hingga ke bupati/walikota.

Atas fenomena tersebut, Riswandha Imawan menyatakan keberangannya, dengan menulis bahwa parpol selalu menjadi free-rider (penumpang gelap) dari setiap perubahanperubahan penting dalam sejarah politik di Indonesia. Tiap peristiwa politik yang menentukan nasib bangsa ini tidak pernah melibatkan parpol. Mulai Proklamasi 17 Agustus 1945, berdirinya Orde Baru, maupun kejatuhan

\footnotetext{
${ }^{34}$ Lihat Soebadio Sastrotomo, Pejuangan Revolusi, (Jakarta: Pustaka Sinar Harapan, 1987), hlm 11-27. (dalam buku yang ditulis langsung oleh pelaku sejarah untuk Proklamasi Kemerdekaan tersebut, tidak sedikitpun ditemukan keterlibatan Parpol)

${ }^{35}$ Tentang teori-teori yang mengidentifikasi siapa sesungguhnya yang menjadi dalang peristiwa tersebut, lihat Daniel Dhakidae, Op.cit., hIm.200-208.

${ }^{36}$ Lihat Syahri, Ekonomi Politik Kebutuhan Pokok, Sebuah Tinjauan Prospektif, (Jakarta : LP3ES, 1986), HIm, 123-126.

${ }^{37}$ Sebenarnya ada banyak teori tentang jatuhnya Orde Lama, Verdi R. Hadiz misalnya, menulis bahwa lahirnya Orde Baru tidak hanya karena kemenangan TNI dalam persaingannya dengan PKI, juga bukan saja pertanda kemenangan antara kaum borjuasi atau kelas menegah kota terhadap kekuatan radikal kiri. Lahimya Orde Baru adalah hasil pergulatan tingkatAsia Tenggara dan Dunia -hasil dari Perang Dingin. Tanpa eskalasi perang Vietnam dan konteks eskalasi Perang Dingin, maka jendral Soeharto dan TNI tidak akan mudah mendapatkan dukungan dari barat untuk menghancurkan kekuatan Kaum Kiri (PKI) di Indonesia. Lihat, Verdi R. Hadiz.op.cit hlm. xxxii.
} 
Soeharto 1998. Bahkan, parpol hadir "karena undangan" pemerintah. Mulai pengisian Volksraad 1918, Maklumat Pemerintah 1945, sampai ke Maklumat Habibie 1999.38

Memang, tidak progresifnya peran partai dapat juga dikaitkan karena partai dalam sejarah politik di Indonesia beberapa kali dipinggirkan oleh dominasi kekuasaan, ditahun 1960 misalnya, Masyumi dan PSI sebagai partai yang berpengaruh saat itu dibubarkan Soekarno karena tokoh-tokohnya dianggap terlibat pemberontakan. ${ }^{39}$ Sementara pada tahun 1973, tidak lama setelah Golkar memenangkan Pemilu 1971, Soeharto memaksa partai-partai yang ada untuk berfusi menjadi dua partai baru, yaitu Partai Persatuan Pembangunan, dan Partai Demokrasi Indonesia. ${ }^{40}$ Bahkan di bulan Juli 1996 Soeharto juga merusak PDI dengan menggusur Megawati Soekarno Putri dari kepemimpinan $\mathrm{PDI}$ yang berakibat munculnya kerusuhan. ${ }^{41}$

Namun, ketika peranannya dipinggirkan, mestinya parpol dapat mengambil inisiatif untuk melakukan perubahan besar. Belajar dari mahasiswa dan kekuatan pro demokrasi misalnya, ketika mereka di depolitisasi melalui kebijakan Normalisasi Kehidupan Kampus pada tahun 1978 dan penyeragaman asas tunggal tahun $1982{ }_{1}^{42}$ mahasiswa dan kekuatan pro demokrasi tidak tertidur, tapi justru terus melawan dan merongrong kursi kepresidenan Soeharto, sampai akhimya lahir reformasi 1998 yang ditandai dengan tumbangnya penguasa totaliter tersebut.

Sebab itu, berdasar argumentasi sejarah kritis di atas, maka memberikan previllege pada parpol, termasuk pemberian kewenarigan tunggalnya dalam pencalonan pilkada adalah kebijakan yang berlebihan dan a-historis. Karena kenyataannya, parpol tidak memiliki sumbangan berarti dalam setiap sejarah perubahan besar di indonesia.

\section{b. Parpol Tidak Serius Menggarap Kaderisasi}

Kaderisasi adalah urat nadi bagi sebuah organisasi termasuk partai politik. Kaderisasi merupakan proses penyiapan SDM agar kelak mereka menjadi para pemimpin yang mampu membangun peran dan fungsi organisasi secara lebih optimal..$^{43}$ Mengutip pendapat George Sarton;

"Sebab hakiki dalam setiap kemunduran adalah urusan dalam, bukan urusan luar. Jika secara kebetulan kita menyaksikan sebatang pohon tumbang lantaran amukan

${ }^{38}$ Riswandha Imawan "Dikelilingi Serigala Politik" , Jawa Pos, 2 Januari 2006

${ }^{39}$ Bahkan pada bulan April 1961, semua partai politik, kecuali 9 partai politik, yang juga telah lolos dari saringan Presiden dibubarkan. Lihat Rusli Karim, Perjalanan Partai Politik Dilndonesia; Sebuah Potret Pasang Surut, (Jakarta: Rajawali Pers, 1993), hlm. 143-150.

${ }^{40}$ PPP adalah hasil fusi dari NU,Parmusi, dan dua partai kecil Islam yaitu, PSIl dan Perti. Sementara PDI terbentuk dari PNI lama, Parkindo, Partai Katholik, IPKI (sebuah partai kecil yang didirikan pada 1952 dan cenderung menjadi juru bicara bagi kepentingan daerah), dan Murba (Pencerminan samara-samar dari sebuh partai komunis nasional dulu). Lihat R.William Liddle, Partisipasi dan Partai Politik Indonesia PadaAwal Orde Ban, (Jakarta: Pustaka Utama Grafiti, 1992), him 97.

${ }^{41}$ Lihat Verdi R Hadiz, op.cit., him. 138.

${ }^{42}$ Tentang penyeragaman asas lihat, Rusli Karim, op.cit.,him. 219-259.

${ }^{43}$ Khoinddin, Partai Politik danAgenda Transisi Demokras, (Yogyakarta: Pustaka Pelajar, 2004), hlm.113-121. 
taufan, maka seharusnya janganlah kita mengutuk taufan itu atas penumbangannya terhadap pohon tersebut. Semestinya ditujukan pada pohon itu sendiri, karena kebusukan bagian dalamnya". ${ }^{44}$

Pendapat tersebut secara tersirat memberikan pressing betapa pentingnya pembenahan internal yang salah satu bentuknya adalah kaderisasi/pengkaderan. Secara formal misalnya, kaderisasi dapat dijalankan dengan menggunakan mediasi seperti event-event Trainning maupun pelatihan berjenjang, sedangkan secara informal adalah dengan teladan yang mesti ditunjukkan para senior partai.

Sayangnya, kaderisasi dalam parpol menjadi mäsalah yang tidak pernah disentuh dan digarap serius, yang terlihat partai hanya sibuk memproduksi milisi-milisi seperti satgas yang cenderung militeristik dan justru dianggapnya sebagai bagian penting dari pengkaderan.

Pada ranah informal menjadi semakin memprihatinkan, alih-alih memberi teladan buat kadernya, para petinggi dan senior partai justru menyuguhkan black education, ini ditunjukkan oleh mereka yang ada di DPR RI misalnya, yang oleh Cetro disebut Dewan Tuna Nurani45, karena ditengah kondisi masyarakat yang di himpit beban ekonomi, mereka malah menuntut kenaikan gaji. Sedangkan para senior partai yang ada di DPRD tidak kalah parah, dengan banyaknya jumlah anggota dewan yang terancam kena bui karena kasus korupsi. Bahkan fenomena itu dialami hampir seluruh DPRD di Indonesia yang notabenenya adalah orang-orang partai. ${ }^{46}$

Dengan kondisi semacam itu, dimana kaderisasi tidak mampu digarap secara serius oleh parpol, maka mengharap parpol akan menjadi rahim yang akan memproduksi lahirnya calon-calon pemimpin bangsa atau calon pemimpin daerah untuk meneruskan jalan terjal demokrasi menjadi mustahil. Kalaupun ada, maka kader yang akan lahir tidak lebih dari kader-kader karbitan, seperti yang selama ini menjadi sasaran kritikan publik.

Dengan demikian, dalam konteks pencalonan pilkada, ketika parpol tidak mampu melahirkan kader-kader terbaik dan karenanya miskin stok kader, maka ketentuan untuk menunjuk parpol sebagai satu-satunya pemegang tiket dalam kontestasi pilkada menjadi tidak relevan. ${ }^{47}$

\section{Simpulan}

Berdasarkan urain di atas dapat disimpulkan bahwa pertama, kehadiran calon independen dalam pilkada sifatnya mutlak dan

${ }^{44}$ Sarton,George, The Incubation of Westem Culture In The Middle East, di Indonesiakan oleh Moh. Ridwan Assagaf, (Surabaya: Pustaka Progessif, 1977), hlm.53:

${ }^{45}$ Press Release Cetro, Walhi, ICW, Ti-I, PSHK, PERLUDEM, FORMAPPI, 15 November 2005. www.cetro.or.id. pukul 12.35.WIB.

${ }^{46}$ tentang data kasus-kasus korupsi di DPRD, Lihat Ign Ismanto, Op.cit., him 83

${ }^{47}$ Konsultan Partnership for Governance Reform, Bambang Widjayanto, pernah menuntut agar partai Politik justru yang sebaiknya dilarang mengajukan pasangan calonnya, karena secara faktual parpol mengalami masalah dengan pengkaderan yang tidak pernah digarap secara serius. Selain itu parpol juga tidak pernah melibatkan masyarakat umum untuk berpartisipasi dalam penjaringan calon. Dalam Syamsul Arifin. "Pilkada Langsung, Lewat Dua Pintu", www.pikiranrakyat, 4 September 2004.Pukul 22.21.WIB 
Faiz. Urgensi Calon Independen Dalam Pemilihan...

tidak bisa ditawar. Sebab dari berbagai sudut pandang manapun, baik dalam perspektif teoritis mapun empiris, calon independen menemukan arti pentingnya. Kedua, kebijakan yang memberikan otoritas tunggal pada parpol tidak relevan, karena parpol di indonesia sesungguhnya bermasalah. Sebab itu, kalau bangsa ini serius menjadikan pilkada sebagai momentum untuk melakukan perubahan mendasar. Maka revisi terhadap Undang-undang No 32 Tahun 2004 terutama Pasal 56 ayat (2) dan Pasal 59 ayat (1) yang hanya mengakui parpol sebagai satu-satunya pintu wajib menjadi agenda utama. Bentuk revisinya dengan membuka pintu baru bagi calon independen. Sehingga dalam pilkada nanti terdapat dua pintu, yaitu pintu parpol dan pintu calon independen.

\section{Daftar Pustaka}

Amal, Ichlasul (ed), 1996. Teori-Teori Mutakhir Partai Politik, Yogyakarta: PT Tiara Wacana.

Bandoro,Bantarto dkk. (penyunting). 1995. Refleksi Setengah Abad Kemerdekaan Indonesia, Jakarta: CSIS.

Castles, Lance 2004. "Pemilu 2004 dalam Konteks Komparatif dan Historis", Yogyakarta: Pustaka Pelajar.

C.S.T. Kansil dan Julianto,1987. Sejarah Perjuangan Pergerakan Kebangsaan Indonesia. Jakarta: Erlangga.

Denni Indrayana, "Pilkada: Demokratis atau Anarkis", makalah Diskusi Publik Bertema Implikasi Politik Dan Hukum Pencalonan Pilkada Tanpa Mekanisme Konvensiyang diselenggarakan oleh Impress bekerjasama dengan SKH kedaulatan Rakyat, tanggal 1 April 2005 di Yogyakarta. Dhakidae, Daniel. 2003, Cendekiawan dan
Kekuasaan dalam.Negara Orde Baru, Jakarta: Gramedia Pustaka.

Hadiz, Verdi R, 2005. Dinamika Kekuasaan Ekonomi Politik Indonesia Pasca

Soeharto. Jakarta: LP3ES

Harun Alrasid, "Jabatan Presiden Republik Indonesia", Dies rede pada Sidang Senat Terbuka Dies Natalis ke 56 Universitas Islam Indonesia, 8 November 1999.

Irsyam, Mahrus dan Romly, Lily (ed.), 2003. Menggugat Partai Politik, Jakarta: Laboratorium llmu Politik Fisipol UI.

Ismanto, Ign (dkk), 2004. Pemilihan Presiden Secara Langsung 2004, Dokumntasi, Analisis dan Kritik. Jakarta: Kejjasama Kementrian Riset dan Teknologi dan Departemen Politik dan Perubahan Sosial CSIS

J. Linz, Juan, 2001, Menjauhi Demokrasi Kaum Penjahat, Belajar dari Kekeliruan Negara-Negara Lain. Bandung, Mizan Karim,Rusli 1993. Perjalanan Partai Politik Di Indonesia; Sebuah Potret Pasang Surut, Jakarta: Rajawali Pers

Khoiruddin.2004. Partai politik dan Agenda Transisi Demokrasi. Yogyakarta: Pustaka Pelajar

Liddle, R.William,1992. Partisipasi dan Partai Politik Indonesia Pada Awal Orde Baru. Jakarta: Pustaka Utama Grafiti

Lipjhart, Arendj, 1995. Sistem Pemerintahan

Parlementer dan Presidensial. Jakarta:

PT Raja Grafindo Persada

Sarton, George. 1977. The Incubation of Western Culture In The Middle East, di Indonesiakan oleh Moh. Ridwan Assegaf. Surabaya: Pustaka Progessif. Sastrotomo, Soebadio, 1987. Perjuangan Revolusi, Jakarta: Pustaka Sinar Harapan. Syahrir, 1986. Ekonomi Politik Kebutuhan Pokok, 
Sebuah Tinjauan Prospektif, Jakarta: Suara Pembaruan, 10 Desember 2004 LP3ES

Syaidam, Gouzali (ed).1999. Dari Bilik Suara Ke Masa Depan Indonesia, Potret Konflik politik Paca Pemilu Dan Nasib Reformasi. Jakarta: PT Raja Grafindo Persada.

Kompas, 5 Agustus 2002.

Kompas, 11 Februari 2005.

Kompas, 6 September 2005

Kompas 26 Desember 2005 Jawa Pos, 12 Agustus 2005. unw.pikiranrakyat, 4 September 2004 Media Indonesia Online, 09 Desember 2005 www.cetro.or.id , 20 Agustus 2001

AT Institute Online, 03 Februari 2006 Suara Merdeka Online,29 Juni 2005 Election Guide - IFES website, www ifes.org/ eguide/turnout2004.htm

Press Release Cetro, Walhi, ICW, TI-I, PSHK, PERLUDEM,FORMAPPI, 15 November. 2005, dalam unw.cetro. or.id. 